\title{
Pengembangan Bahan Ajar Matematika Berbasis Kontekstual (CTL) Materi Bilangan BulatKelas IV Sekolah Dasar Negeri 3 Rensing Tahun Pelajaran 2014/2015
}

\author{
Oleh: \\ Yuliana Susanti
}

\begin{abstract}
Abstrak: Penelitian pengembangan ini bertujuan untuk mengembangkan produk berupa bahan ajar berbasis kontekstual pada pelajaran Matematika kelas IV SDN No 03 Rensing Tahun Pelajaran 2014/2015. Penelitian ini merupakan penelitian dan pengembangan (Research and Development). Penelitian pengembangan ini menggunakan model pengembangan Borg and Gall yang dilakukan dengan lima tahapan, yaitu analisis kebutuhan, perencanaan, pengembangan draf produk, uji coba lapangan, revisi produk. Metode pengumpulan data yang digunakan dalam penelitian pengembangan ini adalah angket respon siswa dan tes hasil belajar siswa.

Subyek uji coba dalam penelitian ini adalah semua siswa kelas IV SDN 3 Rensing yang berjumlah 22 orang. Produk yang dikembangkan berupa buku siswa dengan pendekatan kontekstual, penilaiannya dilihat dari segi materi dan tampilan. Nilai hasil validasi buku siswa dari segi materi adalah 3,37 sedangkan dari s'egi tampilan adalah 3,12 dengan katagori "valid" dan layak untuk digunakan berdasarkan revisi dari masing-masing validator. Persentase siswa yang memberikan respon positif terhadap buku siswa mencapai $54,6 \%$ dan data yang diperoleh dari tes hasil belajar siswa mencapai $77 \%$. Koefisien determinasi $\left(\mathrm{R}^{2}\right)=0,69$. Artinya $69 \%$ pengaruh pengembangan bahan ajar matematika berbasis kontekstual terhadap hasil belajar siswa. Sehingga dapat disimpulkan dalam penelitian ini pengembangan bahan ajar matematika berbasis kontekstual dengan menggunakan model Borg and Gall dikatakan Valid dan Efektif terhadap pembelajaran pada materi bilangan bulat kelas IV SDN 3 Rensing Tahun Pelajaran 2014/2015.
\end{abstract}

\section{Kata Kunci: Pengembangan, Bahan Ajar, Matematika Kontekstual.}

Abstract: The development of research aims to develop products in the form of teaching materials contextually based on a math class IV SDN No 03 Rensing in the academic year 2014/2015. This study is a research and development (Research and Development). The development of research development model Borg and Gall were conducted with five stages, namely the analysis of needs, planning, development of draft products, field trials, product revision. Data collection methods used in the research are the development of student questionnaire responses and test student learning outcomes.

The subjects to be tested in this study were all fourth grade students of SDN 3 Rensing who was 22 people. Products developed in the form of books students with contextual approach, assessment in terms of materials and appearance. Book value of the validation results of students in terms of material is 3.37, while the display is 3.12 s egi the category of "valid" and unfit for use by the revision of each validator. The percentage of students who responded positively to the students 'books reached $54.6 \%$ and the data obtained from the test results of the students' learning reached $77 \%$. The coefficient of determination (R2) $=0.69$. This means that $69 \%$ influence the development of teaching materials mathematics contextually based on student learning outcomes. It can be concluded in the study of mathematics teaching material development using a model-based 
contextual Borg and Gall said Valid and Effective to learning the material integers grade IV SDN 3 Rensing in the academic year 2014/2015.

Keyword: Development, Instructional Materials, Mathematics Contextual

\section{PENDAHULUAN}

Matematika secara umum didefenisikan sebagai bidang ilmu yang mempelajari pola dari struktur, perubahan, dan ruang, secara informal dapat pula disebut sebagai ilmu tentang bilangan dan angka. Dalam pandangan formalis, matematika adalah penelaahan struktur abstrak yang didefenisikan secara aksioma dengan menggunakan logika simbolik dan notasi matematik.

Banyak orang yang mempertukarkan antara matematika dengan aritmatika atau berhitung. Padahal, matematika memiliki cakupan yang lebih luas dari pada aritmatika. Aritmatika hanya merupakan bagian dari matematika. Dari berbagai bidang studio yang diajarkan di sekolah, matematika merupakan bidang studi yang dianggap paling sulit oleh para siswa, baik yang tidak berkesulitan dalam belajar dan lebih-lebih bagi yang berkelsulitan dalam belajar.

Hudojo dalam Irzani (2010: 4) mengartikan matematika adalah suatu alat untuk mengembangkan cara berpikir. Karena itu matematika sangat diperlukan baik untuk kehidupan sehari-hari maupun dalam menghadapi kemajuan IPTEK, sehingga matematika perlu dibekalkan kepada setiap peserta didik sejak MI/SD, bahkan sejak TK. Namun, matematika yang ada pada hakikatnya merupakan suatu ilmu yang bernalarnya deduktif, formal, dan abstrak, harus diberikan kepada anak-anak MI/SD yang cara berpikirnya masih pada tahap operasi konkret.

Pada pembelajaran dengan pendekatan kontekstual, guru tidak serta merta memberikan solusi dari setiap masalah. Akan tetapi siswa diberikan peluang untuk menyelesaikan permasalahan yang ada dengan bimbingan guru, yaitu dengan guru memancing dengan pertanyaan-pertanyaan sehingga siswa akan menemukan penyelesaian permasalahan yang ada. Dengan demikian, siswa akan dengan aktif untuk mengonstruksi, menemukan dan memahami konsep-konsep matematika untuk pemecahan masalah sehingga siswa diharapkan dapat mengomunikasikan ide, gagasan atau pemikiran dalam pemecahan masalah yang disajikan. 
Masalah utama yang sering dihadapi guru dalam pembelajaran khususnya di kelas IV SDN 3 Rensing adalah bagaimana memulai pembelajaran dengan pembahasan yang di kaitkan dengan keseharian siswa, masih kurangnya variasi metode guru dalam proses pembelajaran, guru masih sulit mengaitkan materi dengan kehidupan nyata siswa, serta buku sumber yang di gunakan guru kurang merangsang siswa agar berfikir riil, hanya terpaku pada konsep-konsep dan menghafal rumusrumus yang ada di buku saja. Melihat keadaan yang ada pada saat observasi di SDN 3 Rensing pada kelas IV, maka salah satu yang dapat digunakan untuk mengurangi masalah tersebut adalah peneliti bermaksud mengembangkan bahan ajar yang dapat membantu siswa membangun konsepnya sendiri melalui kejadian-kejadian nyata dalam kehidupan sehari-hari terkait dengan keberlangsungan proses belajar mengajar terutama pada mata pelajaran matematika. Selain itu pendekatan pembelajaran matematika yang digunakan oleh guru tidak mengarahkan siswa untuk memahami makna dari konsep tersebut, melainkan hanya memberikan konsep yang sudah jadi dalam bentuk rumus-rumus.

Melihat kondisi kegiatan belajar mengajar di atas, maka salah satu yang dapat digunakan untuk mengurangi masalah tersebut adalah dengan memilih bahan ajar yang dapat mencakup materi ajar yang kompleks dengan disertai permasalahan kontekstual sehingga siswa dapat mengasah kemampuannya dalam berfikir logis. Pembelajaran kontekstual merupakan pembelajaran aktif. Pembelajaran ini berpusat pada keaktifan peserta didik. Belajar merupakan aktivitas penerapan pengetahuan, bukan menghafal. Peserta didik "acting” guru mengarahkan.

Bahan ajar dengan menggunakan pendekatan kontekstual (CTL) dapat membantu siswa membangun konsepnya sendiri melalui kejadian-kejadian nyata dalam kehidupan sehari-hari. Dalam proses pembelajaran dapat dimulai dengan menggunakan masalah kontekstual kemudian siswa mengorganisasikan masalah lalu mencoba mengidentifikasi sehingga siswa mampu menyelesaikan masalah dengan caranya sendiri berdasarkan pengetahuan dan pengalaman yang dimiliki.

Oleh karena itu, penulis ingin mengembangkan bahan ajar berbasis kontekstual (CTL) untuk membantu siswa dalam berkemampuan memecahkan permasalahan dalam kehidupan sehari-hari sehingga dapat tercapai tujuan kurikulum yang diharapkan. 


\section{METODE PENELITIAN}

Penelitian ini mengembangkan produk berupa bahan ajar matematika berbasis CTL (Contextual Teaching Learning) untuk siswa kelas IV Sekolah Dasar. Agar produk yang akan dikembangkan sesuai dengan tujuan maka penelitian pengembangan ini mengadaptasi model pengembangan Borg and Gall. Model ini terdiri dari 10 tahapan (Nana Syaodih, 2010: 169-170), yang dimodifikasi menjadi 6 tahapan yakni sebagai berikut:

1. Penelitian dan pengumpulan data (research and information collecting)

Tahap awal ini adalah tahapan pengumpulan data untuk mengetahui kondisi permasalahan yang sesungguhnya seperti kajian pustaka, pengamatan kelas, dan lingkungan sekolah. Penelitian awal atau analisis kebutuhan sangat penting dilakukan guna memperoleh informasi awal untuk melakukan pengembangan. Ini bisa dilakukan misalnya melalui pengamatan kelas untuk melihat kondisi riil lapangan. Kajian pustaka sangat diperlukan sebagai landasan melakukan pengembangan.

2. Perencanaan (planning): pendefinisian kemampuan siswa, perumusan tujuan, penentuan urutan pembelajaran.

3. Pengembangan draf produk (develop preliminary form of product): penyiapan gambaran yang sesuai dengan materi dan rencana pembelajaran, penyusunan bahan ajar, kelengkapan evaluasi.

4. Uji coba lapangan (preliminary field testing): data angket respon siswa dan tes hasil belajar siswa.

5. Penyempurnaan produk: melakukan revisi produk untuk memperbaiki hal-hal yang masih kurang baik hasilnya pada saat uji coba lapangan.

6. Implementasi produk (implementation): melaporkan hasil dalam forum ilmiah melalui seminar dan mempublikasikan dalam jurnal ilmiah.

Untuk mengetahuhi kualitas produk yang dihasilkan berdasarkan kriteria kevalidan dan keefektifan terhadap bahan ajar yang akan digunakan dengan melakukan validasi bahan ajar dan uji coba terbatas. Data yang diperoleh dalam penelitian ini merupakan data kuantitatif dan kualitatif. Data kuantitatif diperoleh dari tes hasil belajar siswa. Sedangkan data kualitatif diperoleh dari penilaian pakar terhadap bahan ajar matematika berbasis kontekstual dan data respon siswa. 
Untuk mendapatkan bahan ajar matematika berbasis kontekstual yang valid dan efektif maka diperlukan instrumen penelitian. Instrumen yang diperlukan dalam penelitian ini adalah (1) lembar validasi buku siswa, (2) angket respons siswa terhadap bahan ajar, dan (3) tes hasil belajar. Adapun instrumen yang dibutuhkan untuk memperoleh bahan ajar matematika berbasis kontekstual yang valid dan praktis adalah sebagai berikut:

1. Lembar Validasi Buku Siswa

Lembar validasi digunakan untuk mengumpulkan data tentang validitas produk. Hasil validasi tersebut digunakan untuk merevisi bahan ajar matematika berbasis kontekstual. Instrumen ini terdiri dari lembar validasi tampilan dan lembar validasi materi.

Penilaian di peroleh dari beberapa indikator dan kriteria tertentu. Data tersebut dirubah menjadi data interval. Skor yang diperoleh kemudian dikonversikan menjadi data kualitatif skala empat, yaitu: (4) sangat valid, (3) valid, (2) kurang valid, dan (1) tidak valid.

2. Lembar Penilaian Ahli tentang Keefektifan Bahan ajar Matematika Berbasis Kontekstual

Adapun instrumen yang digunakan untuk menjaring data keefektifan bahan ajar matematika realistik sebagai berikut:

a. Tes Hasil Belajar

Bentuk tes hasil belajar adalah tes pilihan ganda. Tes diterapkan untuk mengukur seberapa jauh setiap siswa mencapai tingkat pemahaman dan kemampuan yang ditetapkan oleh setiap sasaran yang dituju yaitu hasil belajar yang dioperasionalkan dari rumusan kompetensi dasar yang telah ditetapkan. Pengukuran skor tes adalah untuk mengukur hasil belajar siswa terhadap materi pembelajaran menurut kemampuan ranah kognitif. Pemberian skor soal dengan menggunakan skala bebas, tergantung besarnya bobot setiap butir soal.

Instrumen tes hasil belajar digunakan akhir uji coba bahan ajar matematika berbasis kontekstual. Kepada setiap siswa diberikan lembaran tes hasil belajar. Mereka diminta untuk menjawab setiap soal secara 
individual. Total skor yang diperoleh setiap siswa dalam pelaksanaan tes hasil belajar pada akhir pertemuan merupakan data hasil belajar siswa. Adapun kriteria keefektifan bahan ajar matematika berbasis kontekstual ditinjau dari tes hasil belajar siswa, dikatakan tercapai jika paling sedikit 75\% siswa subjek uji coba mencapai tingkat hasil belajar minimal tinggi. Apabila kriteria tersebut belum dipenuhi maka dilakukan revisi terhadap bahan ajar berdasarkan hasil uji coba. Sebelum instrumen tes hasil belajar digunakan, maka terlebih dahulu dilakukan uji kelayakan instrumen yang meliputi uji validitas, dan reliabilitas instrumen melalui data hasil belajar uji coba.

(1) PenentuanValiditas

Berkaitan dengan pengujian validitas instrumen Arikunto (1995:63) dalam Riduan (2010:97) menjelaskan bahwa yang dimaksud dengan validitas adalah suatu ukuran yang menunjukkan tingkat keandalan atau kesahihan suatu alat ukur. (Sugiyono, 2014: 228) mengemukakan perhitungan korelasi dilakukan rumus product moment sebagai berikut.

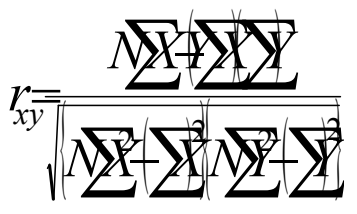

Keterangan:

$X=$ Skor butir

$Y=$ Skor total

$N \quad$ = jumlah responden (subjek)

$r_{x y}=$ Koefisien korelasi skor butir dan skor total.

Untuk interpretasi terhadap besarnya koefisien korelasi, harga $r_{\text {bitung }}$ dikonsultasikan dengan harga $r_{\text {tabel }}$ dengan taraf kesalahan $5 \%$. Jika harga $r_{\text {bitung }}$ yang diperoleh lebih besar dari $r_{\text {tabel }}$ maka butir soal tersebut dikatakan valid, namun jika harga $r_{\text {bitung }}$ yang diperoleh lebih kecil dari $r_{\text {tabel }}$ maka butir soal tersebut direvisi atau dibuang.

(2) Penentuan Reliabilitas 
Instrumen yang reliabel adalah instrumen yang dapat digunakan oleh siapa saja, kapan saja, dan dimana saja. Perhitungan koefisien reliabilitas dapat dilakukan dengan menggunakan rumus $\mathrm{KR}$ 20 (Kuder Richardson), (Arikunto, 2010: 231).

$$
r_{11}=\frac{n}{(n-1)}\left[\frac{s^{2}-\Sigma p q}{s^{2}}\right]
$$

Keterangan,

$r_{11}=$ Reliabilitas

$\mathrm{P}=$ Proporsi subyek yang menjawab item dengan benar

$\mathrm{q}=$ Proporsi subyek yang menjawab item dengan salah

$\sum p q=$ Jumlah hasil perkalian antara $\mathrm{p}$ dan $\mathrm{q}$

$\mathrm{N} \quad=$ Banyaknya item

$\mathrm{S}=$ Standar deviasi dari tes.

b. Angket respon siswa terhadap pembelajaran

Instrumen ini digunakan untuk mendapatkan data mengenai pendapat siswa tentang (1) perasaan siswa senang/tidak terhadap kegiatan pembelajaran, (2) pendapat siswa terhadap komponen pembelajaran, (3) minat siswa untuk mengikuti pembelajaran dengan model pembelajaran matematika dengan pendekatan kontekstual, (4) siswa memahami dengan jelas/tidak bahasa yang digunakan dalam BS, dan (5) siswa tertarik/tidak dengan penampilan (tulisan, ilustrasi/gambar dan letak gambar), yang terdapat dalam BS.

\section{Uji Prasyarat Analisis}

\section{Uji Normalitas}

Pada penelitian ini uji normalitas data akan menggunakan metode chi kuadrat.

$$
\chi^{2}=\sum \frac{\left(f_{0}-f_{h}\right)^{2}}{f_{h}}
$$

Keterangan : 
$\chi^{2}$ : Untuk menguji signifikasi perbedaan frekuensi yang diobservasi

$f_{0} \quad$ : Frekuensi yang diperoleh berdasarkan data

$f_{h} \quad$ : Frekuensi yang diharapkan

Kriteria: jika $x^{2}$ di hitung $<x^{2}$ tabel maka data tersebut berdistribusi normal dengan derajat kebebasan (dk), $\delta=5 \%$.

\section{Uji Linieritas}

Langkah-langkah untuk menghitung linieritas adalah sebagai berikut:

a) Menghitung jumlah kuadrat error $\left(\mathrm{JK}_{\mathrm{E}}\right)$ dengan rumus:

$\mathrm{JK}_{\mathrm{E}}=\sum_{k}\left\{\sum Y^{2}-\frac{\left(\sum Y\right)^{2}}{n}\right\}$

b) Menghitung jumlah kuadrat tuna cocok $\left(\mathrm{JK}_{\mathrm{TC}}\right)$

$\mathrm{JK}_{\mathrm{TC}}=\mathrm{JK}_{\mathrm{Res}}-\mathrm{JK}_{\mathrm{E}}$ dengan $\mathrm{JK}_{\mathrm{Res}}=\sum Y^{2}-\mathrm{JK}_{\mathrm{Reg}(\mathrm{b} / \mathrm{a})}-\mathrm{JK}_{\mathrm{Reg}(\mathrm{a})}$

Dimana: $\mathrm{JK}_{\mathrm{Reg}(\mathrm{a})}=\frac{\left(\sum Y\right)^{2}}{n}$ dan $\mathrm{JK}_{\mathrm{Reg}(\mathrm{b} / \mathrm{a})}=\mathrm{b}\left\{\sum X Y-\frac{\sum X \sum Y}{n}\right\}$

c) Menghitung rata-rata jumlah kuadrat tuna cocok $\left(\mathrm{RJK}_{\mathrm{TC}}\right)$

$\mathrm{RJK}_{\mathrm{TC}}=\frac{\mathrm{JKTC}}{k-2}$

d) Menghitung rata-rata jumlah kuadrat error $\left(\mathrm{RJK}_{\mathrm{E}}\right)$

$\mathrm{RJK}_{\mathrm{E}}=\frac{\mathrm{JKE}}{\mathrm{n}-2}$

e) Mencari $F$ hitung dengan rumus:

F hitung $=\frac{\text { RJKTC }}{\text { RJKE }}$

Keriteria : Jika $\mathrm{F}$ hitung $<\mathrm{F}$ tabel maka data tersebut linier pada derajat kebebasan (dk) dengan $\delta=5 \%$.

\section{HASIL PENELITIAN DAN PEMBAHASAN}

Dalam penelitian ini bahan ajar yang dikembangkan meliputi buku siswa. Adapun model pengembangan yang digunakan dalam penelitian ini adalah model Borg and Gall yang telah dimodifikasi menjadi 6 tahap, yaitu fase analisis kebutuhan (prelimenary investigation), fase desain (design), fase realisasi/konstruksi (realization/construction), dan fase validasi, uji coba dan revisi.

\section{Deskripsi Analisis Kebutuhan}

Tahap analisis kebututhan bertujuan untuk mengetahui apakah merupakan kasus, kesenjangan antara apa yang terjadi dan situasi yang dinginkan, 
maka diperlukan penyelidikan penyebab kesenjangan dan menjabarkannya dengan hati-hati. Dalam analisis tujuannya juga adalah untuk mengumpulkan dan menganalisis informasi, mendefinisikan sebuah masalah dan merencanakan proyek lanjutan.

Analisis kebutuhan siswa SDN 3 Rensing dari persentase respon siswa yang menyatakan kurang menarik lebih banyak dari persentase yang menyatakan menarik yaitu 68\%. Hal tersebut mengakibatkan siswa kadang-kadang merasa kebingungan ketika sedang belajar, sehingga 68\% siswa menyatakan pada konsep konkrit dan konsep abstrak. Pembelajaran yang masih bersifat konvensional atau pembelajaran yang berpusat pada guru kemudian siswa hanya mendengarkan dan mencatat apa yang disampaikan menyebabkan siswa menjadi pasif dan tidak terampil dalam memecahkan masalah. dapat dilihat dari analisis bahwa rata-rata siswa menyatakan guru jarang melatih keterampilan untuk mengembangkan kemampuan berfikir kritis dalam menemukan pemecahan masalah.

\section{Deskripsi Hasil Tahap Perancangan (Design)}

Tujuan dari tahap perancangan (Design) adalah untuk mendesain pemecahan masalah yang dikemukakan pada fase analisis kebutuhan. Hasil dari desain adalah solusi dari masalah yang telah diidentifikasi. Karakteristik kegiatan dalam fase ini adalah merancang draf bahan ajar sesuai dengan langkah pembelajaran matematika berbasis kontekstual.

\section{Deskripsi Pengembangan Produk Awal}

Pada tahap ini bertujuan untuk mengerjakan desain yang telah direncakan pada fase sebelumnya yaitu dengan mengidentifikasi konsep-konsep tentang memahami bilangan bulat. Kemudian menyusun buku siswa sesuai dengan sintaks pembelajaran dengan pendekatan kontekstual. Selanjutnya, buku siswa tersebut divalidasi oleh tim ahli atau validator.

Penilaian validator terhadap buku siswa meliputi 2 aspek yaitu (1) tampilan, dan (2) materi. Hasil penilaian didapatkan rata-rata dari penilaian para validator sebesar 3,24 dengan kategori valid. Dari hasil rata-rata skor tersebut dapat disimpulkan bahwa produk bahan ajar berupa buku siswa layak digunakan, untuk lebih jelasnya dapat dilihat pada lampiran. 
Uji coba terbatas dilaksanakan selama 4 hari, yaitu hari senin 09 Juni 2015, selasa 10 Juni 2015, rabu 11 Juni 2015, dan kamis 12 Juni 2015. Dalam uji coba terbatas diperoleh data tentang hasil belajar siswa dan respon siswa. Adapun rincian secara jelas akan dibahas pada analisis data. Uji coba yang telah dilaksanakan selama 4 kali pertemuan kemudian masing-masing data yang diperoleh akan dianalisis dengan tehnik analisis data yang ada pada bab sebelumnya. Hasil uji coba yang telah dianalisis ini akan digunakan untuk merevisi bahan ajar menghasilkan pengembangan bahan ajar.

\section{Hasil dan Analisis Hasil Belajar Siswa dan Respon Siswa dengan Penedekatan Kontekstual}

Data hasil belajar ini diperoleh dengan memberikan lembar soal tes hasil belajar setelah pembelajaran dengan menggunakan bahan ajar matematika berbasis kontekstual pada materi bilangan bulat, kemudian diiringi dengan pemberian angket respon siswa terhadap proses belajar mengajar dengan menggunakan bahan ajar matematika berbasis kontekstual. Tes hasil belajar ini diberikan kepada 22 siswa SDN No 03 Rensing. Hasil angket persepsi siswa terhadap kegiatan pembelajaran dengan bahan ajar matematika berbasis kontekstual bahwa 27,3\% sangat rendah, 18,1\% rendah, 27,3\% hasil tinggi, dan $27,3 \%$ hasil sangat tiggi. Sedangkan untuk hasil posttest-nya menunjukkan $9 \%$ siswa menunjukkan hasil sangat rendah, 14\% siswa menunjukkan hasil rendah, $36 \%$ siswa dengan hasil belajar tinggi dan 41\% siswa dengan hasil sangat tinggi. Sehingga dapat di nyatakan hasil belajar siswa menggunakan bahan ajar matematika berbasis kontekstual tinggi.

\section{Uji Persyaratan Analisis}

\section{a. Uji Normalitas Data}

Pembukaan normalitas data dilakukan untuk mengetahui apakah skor dalam variabel-variabel yang diteliti berdistribusi normal atau tidak. Untuk menganalisa datanya digunakan rumus chi kuadrat $\left(\mathrm{X}^{2}\right)$. Hasil perhitungan dengan taraf signifikan 5\% dan derajat kebebasan (k-1), dimana $\mathrm{k}$ adalah interval dan kriteria yang digunakan adalah sebagai berikut : jika $\mathrm{X}_{\text {bitung }}^{2}<\mathrm{X}_{\text {tabel }}^{2}$ artinya data dinyatakan normal, sebaliknya jika $\mathrm{X}_{\text {bitung }}^{2}>\mathrm{X}_{\text {tabel }}^{2}$ 
artinya data tidak berdistribusi normal. Untuk lebih jelasnya dapat dilihat pada tabel berikut:

Tabel 1.2

Nilai Uji Normalitas Data

\begin{tabular}{|c|c|c|c|}
\hline \multirow{2}{*}{ Variabel Penelitian } & \multicolumn{2}{|c|}{ Normalitas $\left(\mathrm{x}^{2}\right)$} & \multirow{2}{*}{ Keterangan } \\
\hline & $\mathrm{X}_{\text {bitung }}^{2}$ & $\mathrm{X}_{\text {tabel }}^{2}$ & \\
\hline $\begin{array}{l}\text { Variabel bebas: } \\
\text { Pengembangan bahan ajar } \\
\text { matematika berbasis } \\
\text { kontekstual (basil angket) }\end{array}$ & 2,799 & 12,592 & Normal \\
\hline $\begin{array}{l}\text { Variabel terikat: Bahan ajar } \\
\text { matematika (hasil post test) }\end{array}$ & 5,024 & 12,592 & Normal \\
\hline
\end{tabular}

Berdasarkan tabel 4.6 diatas diperoleh dari hasil analisis angket respon siswa bahwa harga $\mathrm{X}_{\text {hitung }}^{2}=2,799<\mathrm{X}_{\text {tabel }}^{2}=12,592$ sedangkan hasil dari post test siswa bahwa harga $\mathrm{X}_{\text {hitung }}=5,024<\mathrm{X}_{\text {tabel }}^{2}=12,592$. Sehingga data hasil pengukuran variabel berbasis pendekatan kontekstual dan bahan ajar matematika pada materi bilangan bulat kelas IV SDN No 03 Rensing Tahun pelajaran 2014/2015 berdistribusi normal.

\section{b. Uji Linieritas Data}

Uji linieritas data dilakukan untuk mengetahui apakah data tersebut sudah linier atau tidak dan merupakan salah satu syarat supaya data tersebut dapat di uji atau tidak. Untuk menganalisa datanya digunakan rumus teknik uji $\mathrm{F}$, dari hasil perhitungan yang dilakukan dengan menggunakan rumus $\mathrm{F}_{\text {bitung }}=-5,483$ hasil ini kemudian dikonsultasikan dengan nilai $\mathrm{F}_{\text {tabel }}$ taraf signifikan 5\% dan diperoleh harga $\mathrm{F}_{\text {tabel }}=3,20$. Karena $\mathrm{F}_{\text {bitung }}<\mathrm{F}$ tabel maka data tersebut linier.

\section{c. Hasil Analisis Data}

Karena persyaratan analisis telah selesai maka selanjutnya hasil uji analisis menggunakan analisis regresi dengan rumus $\mathrm{Y}=a+\mathrm{bX}$, dari hasil analisis yang dilakukan diperoleh nilai $a=0,558$ dan $b=0,066$ 
sehingga persamaannya $\mathrm{Y}=0,558+0,066 \mathrm{X}$, ini berarti bahwa semakin tinggi hasil belajar siswa maka semakin tinggi kualitas bahan ajar yang dikembangkan. Kemudian dari hasil uji $\mathrm{t}$ maka diperoleh $\mathrm{t}_{\text {bitung }}=$ 6,604 lebih besar dari $\mathrm{t}_{\text {tabel }}=1,725$ artinya Ho ditolak dan Ha diterima. Artinya terdapat perbedaan antara pemahaman sebelum diberikan perlakuan dengan setelah diberikan perlakuan, dengan koefisien determinasi $\left(R^{2}\right)=0,69$. Artinya $69 \%$ pengaruh pengembangan bahan ajar matematika berbasis kontekstual terhadap hasil belajar siswa pada materi bilangan bulat di SDN No 03 Rensing Tahun Pelajaran 2014/2015. Selebihnya ditentukan oleh faktor lain.

\section{Revisi Produk}

Dari hasil tahap perancangan dan setelah dilakukan validasi oleh validator dan ahli dihasilkan bahwa buku siswa yang pada awalnya menggunakan berbagai jenis huruf serta letak gambar pada buku belum tepat. Setelah divalidasi oleh validator, beberapa saran dari validator pada tampilan buku yaitu agar jenis huruf yang digunakan dalam buku disesuaikan dan perbaikan letak gambar serta gambar yang memiliki baground agar tidak menggunakannya sehingga gambar yang satu dengan yang lainnya terlihat menyatu ketika digabungkan.

\section{Kajian Produk Akhir}

Dalam kajian produk akhir dari bahan ajar maka diperoleh produk akhir. Hasil kajian produk akhir tersebut antara lain :

\section{Kevalidan Bahan Ajar Matematika berbasis kontekstual}

Dari hasil validasi oleh validator didapat skor sebesar 3,12 dari ahli tampilan dengan kategori valid dengan rentang skor 3,66 $>X \geq 3,12$, sedangkan dari ahli materi didapat skor sebesar 3,44 dengan kategori valid dengan rentang skor 3,52 $>X \geq 3,37$. Rata-rata skor validasi buku siswa secara keseluruhan adalah 3,24, maka buku siswa dikatakan valid. Untuk lebih jelasnya dapat dilihat pada lampiran.

\section{Keefektifan Pembelajaran dengan Pendekatan Kontekstual}

Keefektifan pembelajaran dengan pendekatan kontekstual diperoleh dari hasil uji coba lapangan. Adapun hasil uji coba sebagai berikut : 
a. Tes Hasil Belajar

Siswa yang mengikuti tes hasil belajar berjumlah 22 orang. Dari tes hasil belajar siswa setelah dianalisis menunjukkan 2 orang dengan skor sangat rendah persentasenya 9\%,0\% dengan skor rendah, 11 orang dengan skor tinggi persentasenya 50\%, dan 9 orang dengan skor sangat tinggi persentasenya 41\%. Sehingga 20 siswa dinyatakan tuntas dengan persentase 91\%, karena persentase ketuntasan lebih dari 85\% maka pembelajaran dengan bahan ajar matematika berbasis kontekstual dikatakan efektif terhadap hasil belajar siswa.

b. Respon Siswa

Sama seperti tes hasil belajar, siswa yang mengisi angket respon berjumlah 22 orang. Dari angket respon siswa setelah dianalisis menunjukkan 6 orang dengan skor sangat rendah (tidak setuju) persentasenya 27,3\%, 4 orang dengan skor rendah (kurang setuju) persentasenya 18,1\%, 6 orang dengan skor tinggi (setuju) persentasenya 27,3\%, dan 6 orang dengan skor sangat tinggi (sangat setuju) persentasenya 27,3\%. Oleh karena itu, skor tinggi dan sangat tinggi berjumlah 54,6\%. Sehingga dari hasil angket respon siswa diperoleh 54,6\% siswa setuju dengan penggunaan bahan ajar matematika realistik dalam proses pembelajaran. Sehingga dapat dikatakan bahan ajar matematika berbasis kontekstual pada kajian akhir dinyatakan valid dan efektif.

\section{SIMPULAN DAN SARAN}

\section{A. Simpulan}

Berdasarkan hasil penelitian pengembangan bahan ajar matematika berbasis kontekstual pada materi bilangan bulat kelas IV SDN No 03 Rensing Tahun Pelajaran 2014/2015, dapat diambil kesimpulan sebagai berikut:

1. Dari hasil analisis angket kebutuhan siswa menyatakan strategi pembelajaran yang digunakan oleh guru dalam pembelajaran matematika masih kurang membuat siswa tertarik untuk belajar matematika, hal tersebut terlihat dari persentase respon siswa yang menyatakan kurang menarik lebih banyak dari persentase yang menyatakan menarik yaitu 68\%. Hal tersebut mengakibatkan siswa kadang-kadang merasa kebingungan ketika sedang belajar, sehingga 68\% siswa menyatakan pada konsep konkrit dan konsep abstrak. Pembelajaran yang 
masih bersifat konvensional atau pembelajaran yang berpusat pada guru kemudian siswa hanya mendengarkan dan mencatat apa yang disampaikan menyebabkan siswa menjadi pasif dan tidak terampil dalam memecahkan masalah. dapat dilihat dari analisis bahwa rata-rata siswa menyatakan guru jarang melatih keterampilan untuk mengembangkan kemampuan berfikir kritis dalam menemukan pemecahan masalah.

2. Hasil pengembangan pada penelitian ini berupa bahan ajar matematika berbasis pendekatan kontekstual (Contextual Teaching Learning) pada materi bilangan bulat, yang meliputi Buku Siswa yang Valid dan Efektif. Proses pengembangan bahan ajar mengacu pada model Borg and Gall dengan tahapan analisis kebutuhan, tahap perancangan (desigen), tahap pengembangan produk, dan tahap validasi, uji coba, revisi.

3. Dari hasil validasi oleh validator pada buku siswa didapat skor sebesar 3,12 dari ahli tampilan dengan kategori valid dengan rentang skor 3,66 $>X \geq 3,12,3,37$ dari ahli materi dengan kategori valid dengan rentang skor 3,52 $>X \geq 3,37$. Siswa yang mengikuti tes hasil belajar berjumlah 22 orang. Dari tes hasil belajar siswa setelah dianalisis menunjukkan 20 siswa dinyatakan tuntas dengan persentase 91\%, karena persentase ketuntasan lebih dari 85\% maka pembelajaran dengan bahan ajar matematika berbasis kontekstual dikatakan efektif terhadap hasil belajar siswa. Sedangkan dari angket respon siswa setelah dianalisis menunjukkan $54,6 \%$ siswa setuju dengan penggunaan bahan ajar matematika berbasis kontekstual dalam proses pembelajaran. Sehingga dapat dikatakan bahan ajar matematika berbasis kontekstual pada kajian akhir dinyatakan valid dan efektif.

4. Dari hasil analisis data didapat hasil uji analisis menggunakan analisis regresi dengan rumus $\mathrm{Y}=a+\mathrm{bX}$, dari hasil analisis yang dilakukan diperoleh nilai $a=$ 0,558 dan $b=0,066$ sehingga persamaannya $\mathrm{Y}=0,558+0,066 \mathrm{X}$, ini berarti bahwa semakin tinggi hasil belajar siswa maka semakin tinggi kualitas bahan ajar yang dikembangkan. Kemudian dari hasil uji t maka diperoleh $\mathrm{t}_{\text {bitung }}=$ 6,604 lebih besar dari $\mathrm{t}_{\text {tabel }}=1,725$, artinya Ho ditolak dan Ha diterima. Artinya terdapat perbedaan antara pemahaman sebelum diberikan perlakuan dengan setelah 
diberikan perlakuan, dengan koefisien determinasi $\left(R^{2}\right)=0,69$. Artinya $69 \%$ pengaruh pengembangan bahan ajar matematika berbasis kontekstual terhadap hasil belajar siswa pada materi bilangan bulat di SDN No 03 Rensing Tahun Pelajaran 2014/2015. Selebihnya ditentukan oleh faktor lain, untuk lebih jelasnya dapat dilihat pada lampiran.

\section{B. Saran Pemanfaatan Desiminasi dan Pengembangan}

Saran-saran yang dapat diberikan penulis sebagai sumbangan pemikiran terhadap pemanfaatan desiminasi dan pengembangan bahan ajar khususnya dalam pembelajaran matematika sebagai berikut:

1. Sehubungan dengan hasil penelitian, maka hendaknya para pengguna bahan ajar dengan pendekatan kontekstual yang dikembangkan di dalam penelitian ini sebagai refrensi pengembangan berikutnya.

2. Pengembangan bahan ajar ini bisa dikembangkan pada pokok bahasan yang lain yang sesuai dengan pendekatan kontekstual.

3. Pengembangan bahan ajar mudah-mudahan bisa dilanjutkan ke jenjang yang lebih luas dan materi yang lain pada matematika.

\section{DAFTAR PUSTAKA}

Alwi, Mijahamuddin,dkk. (2013). Penelitian Pendidikan. Pancor: Pada NW

Amri, S \& Ahmad, LK. (2010). Konstruksi Pengembangan Pembelajaran. Surabaya: PT Prestasi Pustakaraya.

Arifin, Zainal. (2012). Penelitian Pendidikan. Bandung: PT Remaja Rosdakarya.

Isjoni. (2007). Cooperative Learning. Pekanbaru: Alfabeta.

Majid, Abdul. (2011). Perencanaan pembelajaran. Bandung: PT Remaja Rosdakarya. 